\title{
Managerial performance: The challenge of the future
}

\author{
P.H. van den Berg and G.P.J. Pelser \\ School of Business Leadership, University of South Africa, Pretoria
}

Measuring the performance of individual managers is difficult in practice because quantitative yardsticks often measure the performance of groups under the control of a manager or the performance of groups spread over departmental boundaries. If managers are measured individually there is a tendency to emphasize quantitative yardsticks only. An effort is also made to measure individual manager's performance by quantifying qualitative yardsticks. The yardsticks that cannot be quantified, that is the innovative aspects of managerial decisions, are thus neglected. The authors propose a model that can be used for the continual improvement of managerial performance. Managerial performance is the degree to which the manager can close the gap between his current and potential performance. The model takes into account that managerial performance consists of both effectiveness and efficiency. The fundamental basis of the model is the creation of continual review sessions that endeavour to improve performance by removal of the causes of substandard performance.

S. Afr. J. Bus. Mgmt. 1986, 17: 149-152

Die beoordeling van die prestasie van individuele bestuurders is prakties moeilik uitvoerbaar omdat kwantitatiewe maatstawe dikwels prestasie van groepe onder ' $n$ bestuurder se beheer, of die prestasie van groepe wat oor departementele grense strek, meet. Indien bestuurders se prestasies individueel beoordeel word, is daar ' $n$ neiging om slegs kwantitatiewe maatstawe te beklemtoon. Daar word ook gepoog om individuele bestuurders se prestasies te meet deur kwalitatiewe maatstawe te kwantifiseer. Die maatstawe wat nie kwantifiseerbaar is nie, dit wil sê die innoverende gedeeltes van ' $n$ bestuurder se besluite, word dus verwaarloos. Die skrywers stel 'n model voor wat gebruik kan word vir kontinue verbetering van 'n bestuurder se prestasie. Bestuursprestasie is die mate waartoe 'n bestuurder die gaping tussen sy huidige en potensiële prestasie kan toemaak. Die model neem in ag dat ' $n$ bestuurder se prestasie uit beide doeltreffendheid (efficiency) en doelmatigheid (effectiveness) bestaan. Die grondslag van die model is die daarstelling van deurlopende hersieningsessies wat poog om prestasie te verbeter deur die oorsake van onderprestering te verwyder.

S.Afr. Tydskr. Bodryts!. 1986, 17: 149-152

\section{Introduction}

The topic of managerial performance has been elucidated by a host of authors and is still eliciting diverse discussion in many forms. From the literature and discussions two main problems are evident namely: (a) what is meant by managerial performance, and (b) how do we measure it.

The purpose of this article is to discuss these two problems and to propose a new model (see Figure 1) for the measurement of managerial performance which could lead to the continuous improvement of performance in an organization.

\section{The meaning of managerial performance}

Various definitions of managerial performance are in use, therefore it is perhaps essential that we define our view of managerial performance.

Managerial performance includes both effectiveness and efficiency. Effectiveness can be defined as doing the right things, and efficiency as doing things right.

Managerial performance constitutes the ability to realize targets or objectives. It is therefore the process of closing gaps in the set of relationships between what a manager does (his performance at present) and what he is expected to achieve (targets or objectives).

These relationships are defined by the expectations of the organization and by the constraints imposed by the manager himself, his position, the organization, and the socioeconomic environment.

\section{The measurement of managerial performance}

Traditionally performance was measured by using the productivity concept of quantity of output compared to quantity of input.

This concept lead to the approach that performance must be measurable in quantitative terms. Although quantitative measurement is preferable in most situations, it does lead to greater emphasis on efficiency rather than effectiveness as will be shown later. Efficiency indexes, if applied at higher levels of management, tend to measure departmental and even divisional performance making it difficult to measure individual managerial performance.

One of the most used and well-known models in South Africa is the REALST model used to measure performance at executive reporting level (Parsons, 1985:73).

The measurement of performance of individual managers - that is the measurement of the achievement of the set of relationships between present performance and expected
P.H. van den Berg* and G.P.J. Petser

School of Business Leadership, University of South Africa,

P.O. Box 392, Pretoria, 0001 Republic of South Africa

-To whom correspondence should be addressed

Accepted May 1986 


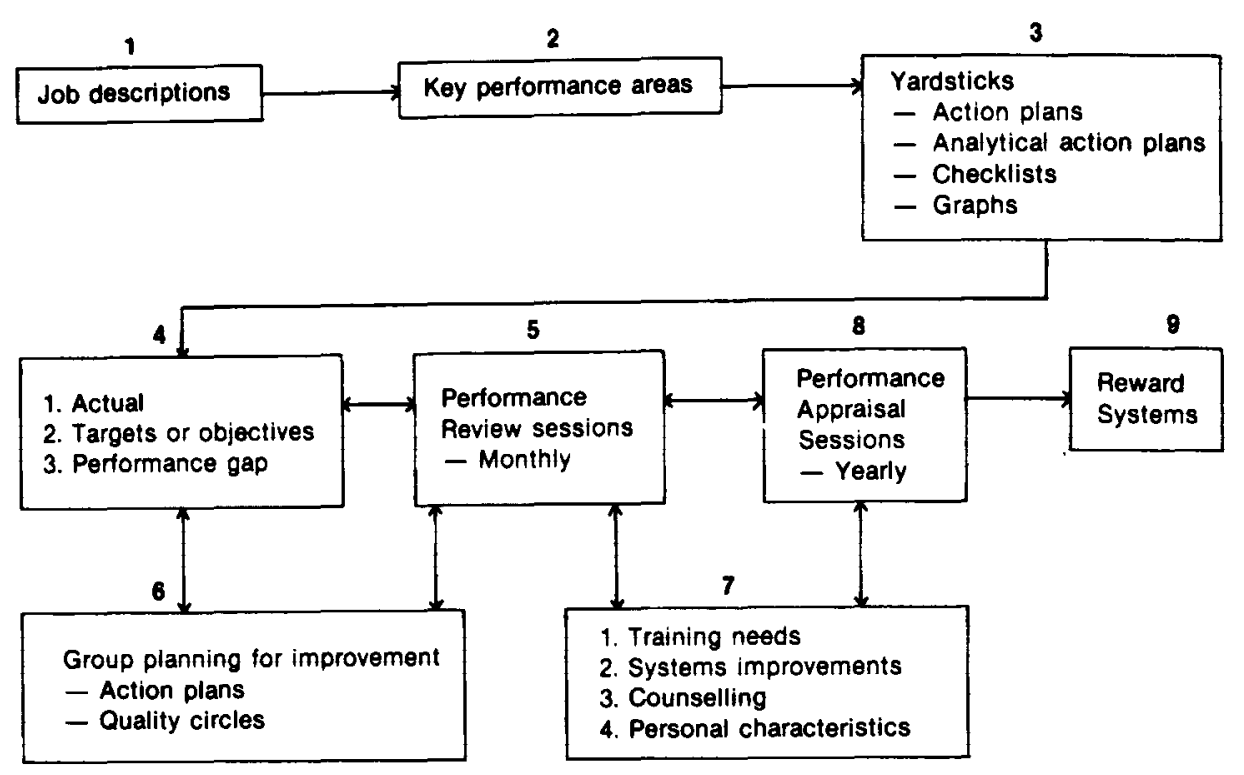

Figure 1 A model for managerial performance improvement

performance - cannot be done by using REALST.

The authors propose to use a model for continuous improvement of performance to overcome the problem of quantification.

To measure individual managerial performance cognizance should be taken of the three prerequisites for acceptable managerial performance:

(i) The requirements of the specific position, that is the characteristics that a person must possess to fit the position (Bennett, 1983:20).

(ii) The behavioural requirements of the manager, that is the skills and experience needed to handle the process of management in that specific position (Bennett, 1983:20).

(iii) The output or product required by that specific position, namely the gap between current performance and what could potentially be achieved or produced (Bennett, 1983:20).

Assuming that prerequisites 1 and 2 are complied with, i.e. we have a person that fits the job, and is skilled and experienced, we can now analyse prerequisite 3 .

Firstly, the process of management of a specific position is modelled by the set of activities called the job description. The job description forms the basis for determining the key performance areas (Figure 1 block 1 and 2). A key performance area is defined as a subset of activities of the job description which provides the biggest contribution towards the achievement of an organization's objectives.

In addition, key performance areas are formulated in such a way that they refer to end-results, that is the output or product required by that position. This required output is transformed to a gap between actual and potential output by making use of yardsticks to measure output.

Broadly, yardsticks can be divided into three classes, namely quantitative yardsticks, qualitative yardsticks, and evaluation of effectiveness. Quantitative yardsticks can be measured in absolute terms and can be presented either as series of numbers or graphically. The average output is referred to as the normal achievable output, for example, walking $5 \mathrm{~km}$ per hour. Qualitative yardsticks are evaluations of the output and relate to the norm expected of such a key performance area. A norm is an expected level of performance generally acceptable in a specific situation. An attempt can be made to quantify this evaluation by defining a number of dimensions of a qualitative yardstick and evaluating each dimension. This set of dimensions are commonly referred to as a checklist.

The third type of yardstick refers to yardsticks needed to measure effectiveness or the result of creative thinking. This is the measurement of plans by evaluation rather than measuring the results of the output of that plan. This type of yardstick is necessary to provide feedback and to stir creativity in the shorter term, because the final output of plans could take years to realise. This type of yardstick is referred to as the evaluation of action plans or evaluation of analytical action plans.

The yardsticks discussed are shown in block 3 of Figure 1.

\section{The performance gap}

Managerial performance was defined as the ability to achieve the closing of gaps in a set of relationships between what a manager does and what is expected of him. The performance gap can be divided into various subgaps as shown in Figure 2.

The actual or current performance is shown and has been defined as the normal or achievable output and is best determined by establishing the average output. The gap between the actual and the capable lines is an efficiency gap and can be closed by doing things right within our existing constraints and resources.

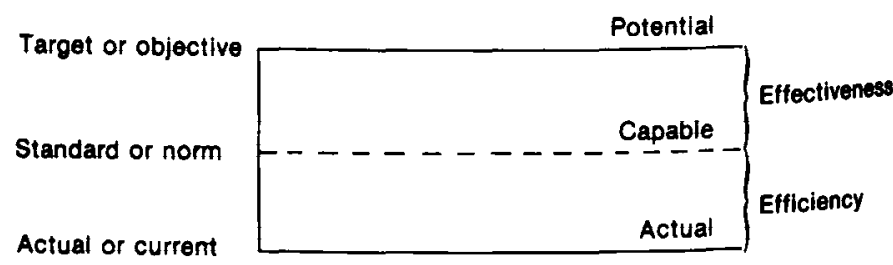

Actual - What we are managing to do now, with existing resources, under existing constraints

Capable - What we could be doing, with existing constraints and resources if we really work at if

Potential - What we ought to do - develop our resources and removing constraints

Figure 2 Components of the performance gap 
The potential line represents what could be achieved by doing the right things such as the development of resources and technology and the removal of constraints. The gap between the capable and potential lines is referred to as the effectiveness gap. Effectiveness is mainly achieved by creative planning and is therefore not always measurable in quantitative terms.

According to Beer, 1981:163 the ratio actual/capable is defined as productivity. The authors define actual/capable as the efficiency gap and capable/potential as the effectiveness gap whilst Beer defined the latter as latency.

According to our definition managerial performance is measured by how the closing or partial closing of the gap between actual and potential, is achieved. By definition, it is the product of the efficiency index and effectiveness index which is

$$
\begin{aligned}
& \frac{\text { actual }}{\text { capable }} \times \frac{\text { capable }}{\text { potential }} \text { or } \\
& \frac{\text { actual }}{\text { potential }}
\end{aligned}
$$

The actual or current performance is what is being achieved at present. The standard relates to capability and represents what can be achieved using the same resources, techniques, etc. The potential is what can be achieved theoretically in an optimal situation, i.e. the optimal use and development of resources, removal of constraints and maximum managerial performance. The target or objective is any point between actual and potential and is therefore the performance gap that we plan to close during a specific time period as shown in Figure 1 block 4 . Note that the potential line is a variable that change over time in the same way that a manufacturing progress curve manifest itself. The performance gap is therefore seldom closed completely.

The question is how to close this gap.

\section{Performance review sessions}

The heart of the performance improvement system is a monthly to three monthly performance review system (see block 5 of Figure 1).

During the review session the key performance areas and yardsticks are the agenda and the discussion centres around the actual performance against planned performance and is therefore the closure of the performance gap.

Note that the system implies that each manager is evaluated against himself because the gap was defined in terms of his key performance areas and yardsticks and his commitment to accept the objective which strives to close the gap between actual and potential.

\section{Group planning}

Group planning (see block 6 of Figure 1) supports the individual manager's aspiration to close the performance gap. These planning groups can take various forms such as quality circles, peer group discussions, and across functional groups. Note that the groups could be used to evaluate performance. This is a powerful way of using group interdynamics but application depends on the culture of the department and the management style of the superior.

\section{Reasons for non-closure of the performance gap}

If the gap cannot be closed, or if the incumbent does not want to commit himself to reasonable objectives, the following actions can be taken (see block 7 of Figure 1):

- The manager can be trained or developed to increase his level of skills and competence.

- Systems can be improved to ensure support of key performance areas or needs for further systems development may be identified. The manager may be in need of counselling and the use of mentors may be appropriate.

- It could be that the manager is not suited to the position. His personality, for instance, could hamper him in achieving closure of the gap.

- Finally, the key performance areas or yardsticks may not be descriptive of the actual position and should be reevaluated.

The performance improvement process is a dynamic, interactive process between blocks 4,5,6 and 7. As the gaps close or widen, they trigger review which either lead to replanning or group planning development which will again effect the gap.

'For the review and follow up process itself, the key requirements are:

1. Evaluation of performance against potential

2. Evaluation of managerial effort

3. Emphasis on the analysis of trends

4. Collaborative attitude of senior management' (Camillus 1976:2).

\section{Performance appraisal sessions}

The monthly or bimonthly performance review sessions can be a source of valuable input to the yearly performance appraisal session and will make substantial reductions in the subjectivity associated with this yearly exercise (see blocks 8 and 9 of Figure 1).

Note that blocks 8 and 9 are part of a merit appraisal system with financial implications for the incumbent whereas the process depicted by blocks $4,5,6$ and 7 is geared for continuous improvement of performance that is, on the short term, not tied to money.

\section{Future challenges}

Business organizations of the future are facing a dynamic, turbulent environment - placing the emphasis on effectiveness rather than efficiency. Efficiency is by definition suitable in a relatively closed system where a stable environment prevails or can be created by managerial buffering actions. Effectiveness can deal with instability and change because it can adapt and change to achieve high performance, although it may loose out on some efficiency. Effectiveness deals with the removal of constraints and the development of resources to exploit the full potential of the organization and thus the full potential of every individual manager. Closing the performance gap can therefore best be attained by innovation and creative thinking.

In this article a system is suggested whereby innovation and creativity can be enhanced:

Firstly, by defining a flexible structure of key performance areas which directs managerial efforts towards issues that affect the organizational performance gap;

Secondly, by measuring the performance of each individual manager and using the result to trigger managerial action; Thirdly, by establishing a performance review system which will influence individual managers to use the group planning potential and to develop themselves towards closing their performance gaps. 
The challenge of the future can only be met by implementing systems such as the above that will add effectiveness (creativity and innovation) to the personal goal of each manager. If this does not happen, organizations will tend to emphasize efficiency and will thereby revert to measuring managers by classifying them into well-known index scales that relate to input and efficiency. The result of such an approach is best summarized in LeBoeuf' The greatest management principle in the world (LeBoeuf, 1985:23):

'The things that get rewarded get done'.

\section{References}

Camillus, J.C. 1976. The Review and Follow-Up Process: Key to Effective Budgetary Control. vol. 1, 1-6.

Beer, S. 1981. The Brain of the Firm. 2nd Edition. New York: John Wiley \& Sons. $214 \mathrm{p}$.

Bennett, R. 1983. Assessing Managerial Performance. Manage. Services. vol. 27, 20-21.

Parsons, J. 1985. Means and Goals. Productivity S. A., vol. II, 71-73.

LeBoeuf, M. 1985. The Greatest Management Principle in the world. New York: G.P. Putman's Sons. 133p. 